\title{
Ecological Restoration and Reforestation of Fragmented Forests in Kianjavato, Madagascar
}

\author{
Christophe Manjaribe, ${ }^{1,2}$ Cynthia L. Frasier, ${ }^{3}$ \\ Bakolimalala Rakouth, ${ }^{1}$ and Edward E. Louis Jr., ${ }^{2,3}$ \\ ${ }^{1}$ Département de Biologie et Ecologie Végétales, Faculté des Sciences, Université d’Antananarivo, BP566, \\ Antananarivo 101, Madagascar \\ ${ }^{2}$ Madagascar Biodiversity Partnership, NGO, VO 12 Bis A, Manakambahiny, Antananarivo 101, Madagascar \\ ${ }^{3}$ Omaha's Henry Doorly Zoo and Aquarium, Center for Conservation and Research, 3701 South 10th Street, Omaha, NE 68107, USA
}

Correspondence should be addressed to Edward E. Louis Jr.; genetics@omahazoo.com

Received 10 January 2013; Revised 19 September 2013; Accepted 30 September 2013

Academic Editor: Ram C. Sihag

Copyright (C) 2013 Christophe Manjaribe et al. This is an open access article distributed under the Creative Commons Attribution License, which permits unrestricted use, distribution, and reproduction in any medium, provided the original work is properly cited.

A reforestation effort in Kianjavato Commune in southeast Madagascar is presented that combines native diversity with rapidly growing introduced and native pioneer trees. This work utilizes a three-tiered corridor design that capitalizes on the region's mountainous terrain. The process of seed selection, transplantation, and survival rate of seedlings over a 16 month period is reported. The uppermost $50 \%$ of each mountain is planted with 38 woody species and most closely approximates native forest. This tier was divided into two categories, pioneer and secondary species. Most of the pioneer species were not native; however, results showed that four fast-growing, environmentally-tolerant native species could be suitable alternatives: Streblus mauritianus, Syzygium bernieri, Treculia madagascariensis and Uapaca thouarsii. More than 70,000 seeds of secondary species were extracted from fecal samples from wild, free-ranging black and white ruffed lemurs; the majority of which germinated significantly better after gut passage. The most effective pretreatment that enhanced germination was to scarify unwashed seeds. Commercially valuable trees, belonging to the community members, were grown on the lower half of each mountain. Lastly, the various contributions of the community are described along with agroforestry development plans designed to reduce pressure on forest resources and generate supplemental income.

\section{Introduction}

Madagascar is world-renowned for its unique biodiversity with entire families of endemic plants and animals. Ensuring the survival of these species is complicated by the poorly regulated use of the country's natural resources. As of 2010, more than $80 \%$ of Madagascar's 16 million rural residents were living below the poverty line [1] and the World Bank [2] reported that $90 \%$ of people living in extreme poverty depend on forest resources as a direct means of support. The combination of poverty and a skyrocketing population has contributed to Maplecroft [3] ranking Madagascar fifth in the world of countries at "Extreme Risk" on the Climate Change Vulnerability Index reflecting the country's perceived inability to withstand climate change.
The country's vulnerability to changing weather patterns coupled with rapid deforestation and political instability threaten Madagascar's citizens and wildlife. More than $40 \%$ of Madagascar's forests were estimated to have been lost between 1950 and 2000 with the deforestation rate escalating since the political coup in 2009 [4-6]. To ensure the survival of Madagascar's wildlife, numerous conservation programs have concentrated on forest corridor identification, protection, and restoration as well as reforestation $[7,8]$.

Two basic methodologies are typically utilized to develop reforestation programs [9]. The first approach uses large numbers of species associated with various successional stages that are planted at high densities, and interactions among this original set of seedlings determine the final forest community $[9,10]$. This method is similar to the "framework 
species method" [11] and was implemented in a Brazilian Amazonia restoration program on a postproduction bauxite mining site [12]. The restored forest composition was similar to that of nearby undisturbed forests after 13 years, but structural recovery had not yet been attained [10]. A similar effort was undertaken in northern parcels of Masoala National Park, Madagascar, using 16 native tree species preferred by frugivorous lemurs, and was designed to reconnect forest fragments by creating corridors $[13,14]$.

The second, more economical approach described by Lamb et al. [9] uses a small number of fast-growing, shortlived tree species to create a canopy. The established canopy shades out competing vegetation and allows for natural colonization from nearby forests primarily from seed dispersal by frugivorous animals [15-17]. This method is similar to the protocol followed by the Bureau de Développement d'Ekar Mananjary in Madagascar that created monoculture plantations of the introduced tree, Acacia mangium (personal communication). The rationale of planting this fire-resistant tree comes from the expectation, as with other legumes, that improvements to soil quality through nitrogen fixation and the presence of a forest canopy will promote natural regeneration [18].

This study concentrates on a pilot project conducted in Kianjavato, Madagascar, that combines native species and fast growing pioneer trees in a large-scale communitybased reforestation and agroforestry initiative. Within this commune is the Foibe Fihofanana momba ny Fambolena (FOFIFA) Kianjavato Coffee Reserve on Sangasanga mountain where substantial degradation was noted by Emberton [19]. Sangasanga and nearby isolated forest parcels are significant as they support two Critically Endangered lemurs, the greater bamboo lemur (Prolemur simus) and the black and white ruffed lemur (Varecia variegata).

A majority of Kianjavato's landscape is classified as degraded humid secondary lowland rainforest, savoka, that is, the result of slash and burn agricultural practices [20]. After several repetitions of slashing and burning, savoka is transformed into roranga or grassland [21]. Roranga is defined as short vegetation $(0.4-1.5 \mathrm{~m})$ dominated by grasses with scattered small trees or shrubs. Forests that are not targeted for agriculture are left fragmented and marooned in a landscape dominated by cropland with a periphery of abandoned roranga or savoka. This abandoned land provides an opportunity for the regrowth of a few fast-growing pioneer species but is often colonized by invasive plants such as Lantana sp. [22, 23]. This interrupts normal migration and foraging behaviors of resident fauna, which can be devastating for local populations of threatened species [24].

To expand habitat and reconnect forest fragments in Kianjavato, the Education Promoting Reforestation Project (EPRP) was created. This grassroots program works directly with local leaders and residents to plant corridors across the roranga and savoka to connect the remaining vestiges of forests from the eastern to the western borders of Kianjavato Commune. These corridors are intended to accelerate natural colonization and succession and enable the movement of previously isolated wildlife. However, a limitation associated with large-scale reforestation efforts using native species is the production of sufficient quantities of seedlings adapted to the local environment. To maximize seedling production, it was predicted that utilizing seeds extracted from the feces of the black and white ruffed lemur, the primary seed disperser in Kianjavato's forest, would increase the production of seedlings in comparison to extracting seeds from ripe fruits as gut passage often increases germination performance [2527].

Although the conversion of forest to agricultural lands theoretically provides greater access to food, there is no mechanism in Kianjavato, Madagascar, to replace the ecological services provided by the razed forest. The EPRP model aims to restore ecosystem services by approximating a native forest using gut passed seeds and a modified framework species method [11]. To address the socioeconomic factors that led to the initial deforestation, the EPRP will provide supplemental income through the growth of timber and nontimber products to provide benefits to area residents greater than those extracted from slash and burn farming. With these objectives the present study was undertaken.

\section{Methods}

2.1. Site Description. This research was conducted in the commune of Kianjavato, located in southeastern Madagascar between Ranomafana National Park and the coastal city of Mananjary. Kianjavato is within the Vatovavy-Fitovinany Region and the province of Fianarantsoa (Figure 1). The study was carried out as a pilot project in the eastern portion of Kianjavato Commune from Vatovavy Classified Forest across unprotected, deforested habitat to the Kianjavato Ahmanson Field Station (KAFS) operated by the Madagascar Biodiversity Partnership and Omaha's Henry Doorly Zoo and Aquarium (Figure 2). The reforestation corridor included 11 mountains and nine valleys, with $80 \%$ of the area consisting of roranga and $20 \%$ of savoka. Valleys were intensively farmed, mostly for rice cultivation, and were not part of the reforestation project. In total, the area of the pilot project corridor was approximately 80 ha ranging from 75 to $350 \mathrm{~m}$ wide. All necessary permits were arranged through national and local Malagasy Ministry of Environment and Forests offices.

The natural vegetation surrounding Kianjavato is low elevation humid evergreen forest with a tree flora dominated by Anthostema and Myristicaceae [28]. The local topography is hilly with elevations ranging from 52 to $571 \mathrm{~m}$ and the local climate is characterized by an annual rainfall of $1,800 \mathrm{~mm}$, falling mostly between the months of December and March. The mean annual temperature is $23.4^{\circ} \mathrm{C}$, with monthly means ranging from $16.1^{\circ} \mathrm{C}$ in June to $30.7^{\circ} \mathrm{C}$ in January (FOFIFA weather station, 2011). During the rainy season, the region can experience devastating cyclones.

2.2. Community Acceptance and Involvement. Prior to beginning any field-based work, the community was approached to gauge their interest and support for a local reforestation effort. Meetings were arranged with the mayor, representatives from each local village, Fokontany (the lowest recognized administrative subdivision) presidents, local traditional authority 


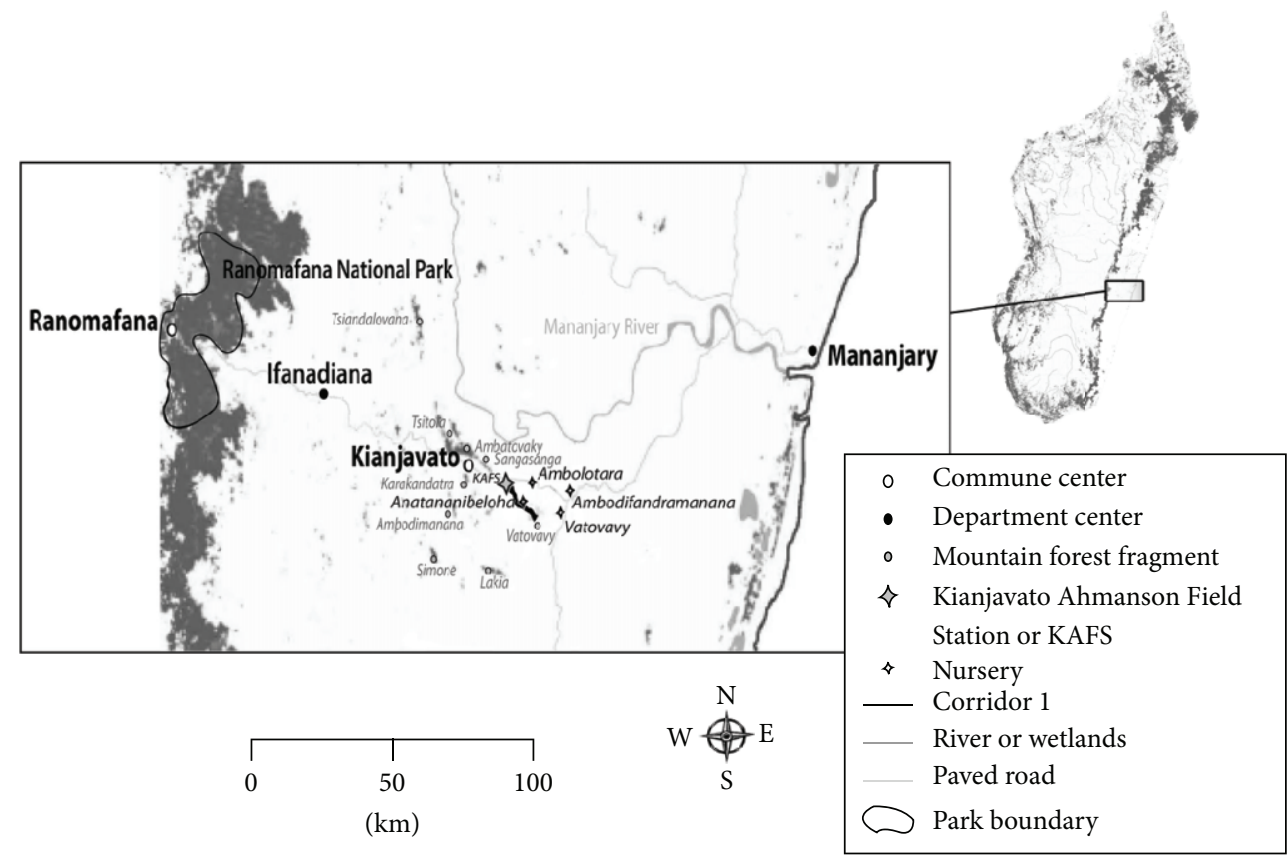

FIgURE 1: Study site for the Education Promoting Reforestation Project (EPRP) in Kianjavato Commune, Madagascar. Varecia variegata fecal samples were collected from Ambatovaky, Sangasanga, and Vatovavy as sources of seeds for the Permanent Tier.

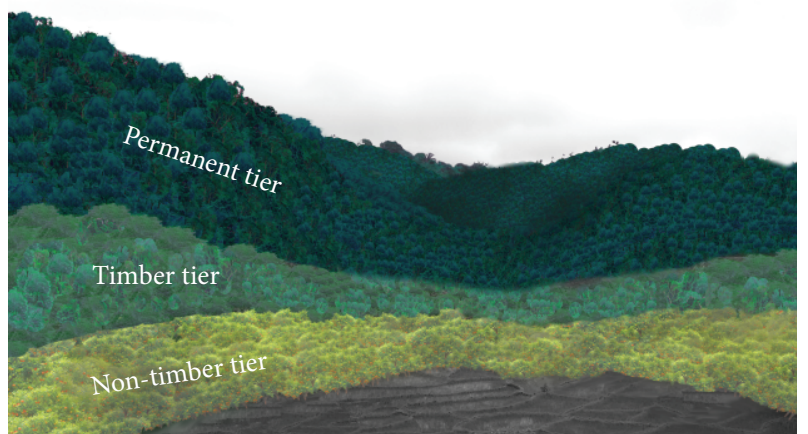

FIgURE 2: The three-tiered corridor design incorporating a Permanent Tier composed of mainly native tree species on the upper $50 \%$ of hills, that is, not subject to harvest and two commercial layers, the Timber and Non-Timber Tiers, occupying the lower 50\% of the hill that can be sustainably harvested. Agriculture on valley floors was not disrupted by this reforestation program.

figures, and school employees. The objective was to communicate the benefits of intact forests to the community, generate enthusiasm, obtain feedback, and reduce possible future land-use conflicts.

2.3. Corridor Design. In order to develop a community-based cooperative program and establish permanent corridors for the biodiversity in this region, the landscape was divided into three tiers as follows: Permanent, Timber, and NonTimber (Figure 2). The Permanent Tier occupies 50\% of the land committed to the reforestation project and is situated on the upper half of the mountains. It predominantly includes species consumed by $V$. variegata and has the greatest diversity of all the tiers. This portion of the corridor most closely resembles the natural assemblage found in nearby intact forest patches with the addition of pioneer species to provide rapid canopy cover. The Permanent Tier will not be subject to harvesting and fulfills the role of restoring ecological services; the pilot project focused mostly on this tier.

The remaining half of the forest corridor is occupied by the Timber and Non-Timber Tiers. The Timber Tier occupies $35 \%$ of the corridor starting just below the Permanent Tier. It includes species most frequently used by the local community for fuel and construction. The species repertoire of this tier overlaps slightly with the Permanent Tier and will be subject to sustainable harvesting. The Non-Timber Tier provides fruit and other products of commercial value and was planted in the lowest $15 \%$ of the corridor nearly abutting the rice fields.

2.4. Species Selection. There are two categories of trees within the Permanent Tier, pioneer and secondary species (Table 1; family affiliations follow APG III [29] and the Catalogue of the Vascular Plants of Madagascar [30]). Four pioneer species were used for the reforestation corridor (Table 1) as they are considered to be fast growing and tolerant to both sun exposure and poor soil conditions. These include the introduced species, Albizia chinensis, A. lebbeck, and A. saman of the Fabaceae family, which is known for its nitrogenfixing abilities. The native Harungana madagascariensis was also used as a pioneer species. The secondary species of the Permanent Tier were collected from black and white ruffed lemur fecal samples from three sites in Kianjavato Commune: 
TABle 1: Species used in the Education Promoting Reforestation Project organized by tier and family.

\begin{tabular}{|c|c|c|c|}
\hline Tier & Family & Scientific name & Vernacular name \\
\hline \multirow[t]{4}{*}{ Permanent (Pioneer) } & Fabaceae & Albizia chinensis (Osbeck) Merr. & Aliboza \\
\hline & Fabaceae & Albizia lebbeck (L.) Benth & Bonary \\
\hline & Fabaceae & Albizia saman (Roxb.) Benth. & Enga \\
\hline & Hypericaceae & Harungana madagascariensis Lam. ex Poir. & Harongana \\
\hline \multirow[t]{38}{*}{ Permanent (Secondary) } & Acanthaceae & Mendoncia cowanii (S. Moore) Benoist & Vahimpotsy \\
\hline & Anacardiaceae & Abrahamia aff. sericea (Engl.) Randrian. \& Lowry & Malambovony lahy \\
\hline & Anacardiaceae & Poupartia chapelieri (Guillaumin) H. Perrier & Voamainty fotsimaso \\
\hline & Annonaceae & Uvaria combretifolia Diels & Vahy \\
\hline & Apocynaceae & Landolphia aff. gummifera (Poir.) K. Schum. & Voakilimena \\
\hline & Arecaceae & Dypsis fibrosa (C.H. Wright) Beentje \& J. Dransf. & Vonitra \\
\hline & Arecaceae & Dypsis mananjarensis (Jum. \& H. Perrier) Beentje \& J. Dransf. & Lafa \\
\hline & Burseraceae & Canarium boivinii Engl. & Sandramy \\
\hline & Burseraceae & Canarium madagascariense Engl. & Ramy \\
\hline & Burseraceae & Protium madagascariense Engl. & Rarà \\
\hline & Celastraceae & Salacia madagascariensis (Lam.) DC. & Vahinkakao \\
\hline & Dichapetalaceae & Dichapetalum chlorinum (Tul.) Engl. & Vahinkafe \\
\hline & Euphorbiaceae & Suregada celastroides Radcl.-Sm. \& Petra Hoffm. & Hazomby \\
\hline & Fabaceae & Dalbergia madagascariensis Vatke & Voamboana \\
\hline & Fabaceae & Dupuya haraka (Capuron) J.H. Kirkbr. & Kajaherotrala \\
\hline & Gentianaceae & Anthocleista longifolia (Lam.) Boiteau & Lendemy \\
\hline & Lauraceae & Aspidostemon aff. perrieri (Danguy) Rohwer & Sily \\
\hline & Lauraceae & Beilschmiedia opposita Kosterm. & Hazombato \\
\hline & Lauraceae & Cryptocarya dealbata Baker & Tavolo lavaravina \\
\hline & Lauraceae & Cryptocarya ovalifolia (Danguy) van der Werff & Tavolo boribory \\
\hline & Lauraceae & Cryptocarya thouvenotii (Danguy) Kosterm. & Hazomboanjo \\
\hline & Lauraceae & Ocotea nervosa Kosterm. & Varongy \\
\hline & Menispermaceae & Burasaia madagascariensis DC. & Vodihazo teloravina \\
\hline & Moraceae & Streblus mauritianus (Jacq.) Blume & Ampaliala \\
\hline & Moraceae & Treculia madagascarica N.E. Br. & Friampaly \\
\hline & Moraceae & Trophis montana (Leandri) C.C. Berg & Mahanoro \\
\hline & Myrtaceae & Syzygium bernieri (Drake) Labat \& G.E. Schatz & Voamborizany \\
\hline & Oleaceae & Noronhia introversa $\mathrm{H}$. Perrier & Tsilaitra beravina \\
\hline & Oleaceae & Noronhia urceolata $\mathrm{H}$. Perrier & Tsilaitra madinidravina \\
\hline & Phyllanthaceae & Uapaca thouarsii Baill. & Voapaka \\
\hline & Rhamnaceae & Bathiorhamnus louvelii (H. Perrier) Capuron & Hazoaraka \\
\hline & Rhamnaceae & Bathiorhamnus macrocarpus (Capuron) Callm., Phillipson \& Buerki & Hazoaraka beravina \\
\hline & Rubiaceae & Coffea perrieri Drake ex Jum. \& H. Perrier & Kafeala \\
\hline & Sapindaceae & Macphersonia gracilis $\mathrm{O}$. Hoffm. & Voanemba/Sanira \\
\hline & Sapindaceae & Tina apiculata (Radlk.) Radlk. ex Choux & Letsy ala \\
\hline & Sapotaceae & Chrysophyllum boivinianum (Pierre) Baehni & Rahiaka \\
\hline & Sapotaceae & Chrysophyllum perrieri (Lecomte) G.E. Schatz \& L. Gaut. & Voantsikidy \\
\hline & Sapotaceae & Sideroxylon betsimisarakum Lecomte & Tavia \\
\hline \multirow[t]{5}{*}{ Timber } & Euphorbiaceae & Croton mongue Baill. & Molanga \\
\hline & Euphorbiaceae & Suregada celastroides Radcl.-Sm. \& Petra Hoffm. & Hazomby \\
\hline & Fabaceae & Dalbergia madagascariensis Vatke & Voamboana \\
\hline & Lauraceae & Cryptocarya dealbata Baker & Tavolo lavaravina \\
\hline & Meliaceae & Khaya madagascariensis Jum. \& H. Perrier & Hazomena \\
\hline
\end{tabular}


TABle 1: Continued.

\begin{tabular}{lccc}
\hline Tier & Family & Scientific name & Vernacular name \\
\hline Non-timber & Anacardiaceae & Anacardium occidentale L. & Voambarika \\
& Annonaceae & Annona muricata L. & Voantsokina \\
& Annonaceae & Znnona squamosa L. & Kily \\
& Fabaceae & Tamarindus indica L. & Ravintsara \\
& Lauraceae & Cinnamomum camphora (L.) J. Presl & Zavoka \\
& Lauraceae & Kersea americana Mill. & Kakao \\
& Malvaceae & Theobroma cacao L. & Ananambo \\
& Moringaceae & Moringa oleifera Lam. & Litchi \\
Sapindaceae & Nephelium litchi Cambess. &
\end{tabular}

Ambatovaky, Sangasanga, and Vatovavy (Figure 1). These species are typical of mature forests and represent the fruitbased portion of the lemurs' diets and were predicted to grow more slowly than the pioneer species.

Suregada celastroides, Cryptocarya dealbata, and Dalbergia madagascariensis are included in the Permanent Tier as well as the Timber Tier as they are valued for their wood. The leaves, not the fruits, of the latter species are consumed by $V$. variegata. The Timber Tier also includes Croton mongue and Khaya madagascariensis that are frequently used by local residents for construction and as handles for tools. Additional species of economic importance were selected for the NonTimber Tier (Table 1) that do not require harvesting of the tree itself but provide fruits and essential oils. These include Anacardium occidentale (cashew), Annona squamosa (custard apple, sweetsop, or zaty), Annona muricata (beef heart or soursop), Cinnamomum camphora (ravintsara), Moringa oleifera (ananambo), Persea americana (avocado), Tamarindus indica (tamarind), and Theobroma cacao (chocolate). Nephelium litchi (litchi) was added at a later date as it is a proven income generator and performs well.

2.5. Seed Collection, Germination, and Statistical Analysis. Seeds of pioneer, timber, and non-timber trees were purchased from regional and local seed vendors. Seeds of secondary species were obtained by following black and white ruffed lemur groups and collecting fecal samples. Varecia variegata individuals were immobilized following the protocol described by Louis et al. [31]. Selected individuals from different family groups were fitted with radio collars to facilitate monitoring and collection of fecal samples by local field assistants [32, 33]. Fecal samples were bagged individually and collection was done throughout the year to ensure that all dominant food species were represented in the reforested corridors. Each plant species that was seen consumed by the black and white ruffed lemur was noted and marked and voucher specimens were identified by botanists at the national herbarium (TAN) and the first author.

Seeds were germinated in a nursery setting where seedlings were raised to be transplanted into the corridor. Seeds for pioneer, timber, and non-timber species were presoaked for 24 hours before sowing into cold frames as recommended by Comtet and Rabevohitra [34], Manjaribe [35], and the Silo Nationale des Graines Forestières (SNGF; unpublished data). Cold frames are simple structures that sit on the ground with enclosed sides and have lids made of light wooden frames with clear plastic stretched across them. The growing medium within the cold frames consisted of a mixture of local soil, compost, and sand. These were positioned under a nursery structure partially shaded by ravenala fronds.

Seeds for the Permanent Tier collected from black and white ruffed lemur fecal samples were subjected to six different treatments to identify the method with the highest germination success to maximize efficiency in seedling production. As seeds from the same fecal sample are not independent, seeds for each treatment per replicate for this study were collected from multiple fecal samples to reduce the likelihood of pseudoreplications [36]. Each treatment in a replication had 100 seeds for a total of 600 seeds per species per replication. Seeds extracted from fecal samples were subjected to four treatments: scarified and washed (SW), scarified not washed (SNW), not scarified and washed (NSW), and not scarified and not washed (NSNW). Seeds were also extracted directly from fruit and scarified (CS) or not scarified (CNS).

Significant differences in germination percentages of treatments were detected using an ANOVA. Although Ftests can be applied to balanced designs as in this work, the heteroscedastic nature of germination trials increases the probability of type 1 errors $[36,37]$. Therefore, ANOVAs were followed by the Tukey HSD test [38], which is more tolerant to data with unequal variance, but with balanced sample sizes.

Two species that were incorporated into the Permanent Tier were not part of the germination trials: Streblus maritianus and Dupuya haraka. The seeds of Streblus maritianus were too small to be scarified, and the seeds of Dupuya haraka were too large to be swallowed by the black and white ruffed lemur. The lemurs eat the fleshy portion of Dupuya haraka fruits and then drop the seeds to the ground. Thus, only data were reported for these species after transplanting seedlings to the field.

After germination, all seedlings were transplanted to polyethylene growing bags with drainage holes. Seedlings were maintained at the nursery for 90-210 days until they reached a height of $15-30 \mathrm{~cm}$. Before planting into the corridor, seedlings were hardened off to better withstand full sun exposure for 15-45 days depending on the planting schedule. 
2.6. Corridor Planting and Evaluation. Bamboo stakes were spaced four meters apart following the contour of the reforestation corridor such that they were parallel to the steepest slope. Seedlings were planted at the base of each bamboo stake with a final density of 625 seedlings per hectare. Holes for the seedlings, approximately $40 \mathrm{~cm}^{3}$ in size, were dug by hand by local residents participating in the pilot program. Grasses and ferns that were cut in the process of digging the holes were used as mulch around the seedlings to capture humidity and provide temporary shade and future biological compost. The area characterized as savoka was near the edge of the Vatovavy forest, which has shade provided by shrubs and trees indicative of this vegetation formation [21]. As the existing canopy was sufficient to provide shade for seedlings and the soil is of a higher quality than in roranga, only Permanent Tier species were planted here. In areas of roranga, species from all tiers were planted following the corridor design. Pioneer species were planted first, and the other species were interplanted among them.

Each seedling was assigned a unique ID number stamped on a metal tag nailed to a eucalyptus stake placed next to it. Seedling survival was evaluated at five and 16 months after planting. Stem basal diameter was measured using calipers at five $\mathrm{cm}$ above the root collar and height was measured from the base to the apex. Additionally, GPS coordinates were recorded for each seedling planted.

\section{Results}

3.1. Seed Germination. For all taxa, seeds germinated an average of 12 to 25 days after sowing except for Albizia chinensis, A. saman, and Annona squamosa which took four to six days. Forty-five to ninety days after sowing, the number of seeds that produced shoots that broke the soil surface was recorded and used to calculate the percentage of seeds that successfully germinated per treatment.

Thirty-eight woody species representing 21 families were collected from $V$. variegata fecal samples and incorporated into the Permanent Tier (Table 1). These species included shrubs, trees, and lianas. No significant negative effects of gut passage by $V$. variegata were observed on the secondary species subjected to the germination treatments except for Cryptocarya thouvenotii (Table 2). Generally, gut passage enhanced germination as all variations of treatments for seeds extracted from feces of 25 species had significantly greater germination than those extracted from fruits $(P<0.05)$. Seeds can be collected from fruit or fecal matter for Cryptocarya and Noronhia species, as differences in the germination percentages for either sets of treatments were not significant. Other than these two genera, there were no clear treatment preferences favored between closely related species.

Seeds extracted from fruits of the following species did not germinate or had nominal germination $(10 \%$ or less): Anthocleista longifolia, Beilschmiedia opposita, Burasaia madagascariensis, Dypsis fibrosa, D. mananjarensis, Macphersonia gracilis, Ocotea nervosa, Poupartia chapelieri, Protium madagascariensis, Sideroxylon betsimisarakum, and Uvaria combretifolia. Species-specific protocols can be derived from
Table 2, but the treatment with the highest overall germination percentage for Permanent Tier species was to scarify unwashed seeds. This treatment performed significantly better than all other treatments for seven species $(P<0.05)$ and had the highest germination percentages for 17 species (Table 2).

3.2. Planting. Transplanting of seedlings into the corridor occurred mostly during the rainy season from January to June. The pioneer species were planted between February and March 2010, and the secondary species were planted in the Permanent Tier between May and June 2010. The Timber and Non-Timber Tiers were planted in mid-December 2010 and April through May 2011. Overall, 53 species were represented in the corridor with more than 21,000 seedlings planted from February 2010 to May 2011.

3.3. Seedling Survival and Growth. After one year, manual weeding was required around the seedlings to improve seedling survival and encourage noncompetitive growth. The first evaluation was performed in June 2010 and focused on the survival of pioneer seedlings. The second evaluation was carried out in June and August 2011 and included all species. The survival and growth of the seedlings in the corridor were used as measures of their performance. The proportion of seedlings that survived six to 16 months varied among site, category, and species.

The pioneer Albizia saman had the highest survival rate of Permanent Tier seedlings at $97.5 \%$, followed by Harungana madagascariensis (94.7\%) and Albizia chinensis (87.4\%) one year after being planted into the reforestation corridor (Table 3). Albizia lebbeck had the lowest survivorship of the pioneer species during the same time period. Predation by herbivores, especially on Albizia saman, was the greatest cause of death for the pioneer species.

Albizia chinensis had the highest relative growth rate in height and stem diameter with some individuals producing flowers and fruits after one year. This species had a mean relative growth rate of $18.7 \mathrm{~cm}$ in height per month and $0.2 \mathrm{~cm}$ in stem basal diameter. Six native secondary species outperformed the remaining pioneer species in growth rate (Table 3).

Survival rates varied widely for secondary species. Poor performance was noted in Tina apiculata, both Chrysophyllum species, Dichapetalum chlorinum, and Ocotea nervosa. The death of the majority of seedlings for all of the aforementioned species occurred mostly in roranga, where survival rates ranged from 5.7 to $23.0 \%$. However, rates improved when these seedlings were planted near the edge of the existing forest in savoka (53.0-80.0\%). The native species with the highest survival rates in roranga and savoka were Anthocleista longifolia, Beilschmiedia opposita, Canarium madagascariense, C. boivinii, Cryptocarya dealbata, Dalbergia madagascariensis, Protium madagascariensis, Streblus maritianus, Suregada celastroides, Syzygium bernieri, Treculia madagascarica, and Uapaca thouarsii (80.0-100.0\%), demonstrating a tolerance for harsher environmental conditions (Table 3). 
TABLE 2: Results of the germination study comparing treatments with standard deviations in parentheses. Four treatments were performed on seeds extracted from feces: SW (scarified and washed), SNW (scarified not washed), NSW (not scarified and washed), and NSNW (not scarified and not washed). Two treatments were performed on seeds extracted from fruit: CS (control scarified), CNS (control not scarified). Treatments in bold text performed significantly better than other treatments. Means sharing the same superscript within a species do not significantly differ from each other (Tukey's HSD, $P<0.05$ ); means determined to be significantly different from all other means do not have a superscript.

\begin{tabular}{|c|c|c|c|c|c|c|c|c|}
\hline \multirow{2}{*}{ Scientific name } & \multirow{2}{*}{$\begin{array}{l}\text { Seeds } \\
\text { planted }\end{array}$} & \multirow{2}{*}{$\begin{array}{l}\text { Number of } \\
\text { Replicates }\end{array}$} & \multicolumn{6}{|c|}{ Treatment (average \% germination) } \\
\hline & & & SW & SNW & NSW & NSNW & CS & CNS \\
\hline Abrahamia aff. sericea & 2400 & 4 & $100.0(0.0)$ & $70.0(2.45)^{\mathrm{a}}$ & $70.0(3.74)^{\mathrm{a}}$ & $70.5(1.29)^{\mathrm{a}}$ & $92.3(3.40)^{\mathrm{b}}$ & $92.3(2.22)^{b}$ \\
\hline Anthocleista longifolia & 1800 & 3 & $39.0(1.73)^{\mathrm{a}}$ & $43.0(1.00)$ & $36.0(2.00)^{\mathrm{ab}}$ & $35.0(1.00)^{\mathrm{b}}$ & $0.0(0.00)^{c}$ & $0.0(0.00)^{c}$ \\
\hline Aspidostemon aff. perrieri & 2400 & 4 & $36.0(3.16)^{\mathrm{a}}$ & $36.0(4.55)^{\mathrm{a}}$ & $45.0(3.83)^{\mathrm{b}}$ & $50.8(1.71)^{\mathrm{b}}$ & $35.0(2.94)^{\mathrm{a}}$ & $45.0(4.97)^{\mathrm{b}}$ \\
\hline Bathiorhamnus louvelii & 2400 & 4 & $39.0(1.41)$ & $63.0(2.58)^{\mathrm{a}}$ & $60.0(2.94)^{\mathrm{a}}$ & $50.0(1.63)$ & $28.0(2.16)$ & $22.0(1.41)$ \\
\hline Bathiorhamnus macrocarpus & 1800 & 3 & $51.0(3.0)^{\mathrm{b}}$ & $69.0(2.00)^{\mathrm{a}}$ & $65.0(1.00)^{\mathrm{a}}$ & $55.0(2.00)^{\mathrm{b}}$ & $24.0(2.00)^{\mathrm{c}}$ & $20.7(3.00)^{\mathrm{c}}$ \\
\hline Beilschmiedia opposita & 1800 & 3 & $50.0(2.00)^{\mathrm{a}}$ & $58.0(1.53)$ & $48.0(1.73)^{\mathrm{a}}$ & $44.0(1.00)$ & $0.0(0.00)^{\mathrm{b}}$ & $0.0(0.00)^{\mathrm{b}}$ \\
\hline Burasaia madagascariensis & 2400 & 4 & $69.0(2.58)$ & $90.8^{\mathrm{a}}(2.99)$ & $57.0(4.08)$ & $88.0^{\mathrm{a}}(2.58)$ & $6.0^{\mathrm{b}}(3.74)$ & $4.0^{\mathrm{b}}(2.71)$ \\
\hline Canarium boivinii & 1800 & 3 & $74.3(1.15)^{\mathrm{a}}$ & $74.0(1.73)^{\mathrm{a}}$ & $75.0(2.00)^{\mathrm{a}}$ & $71.0(2.65)^{\mathrm{a}}$ & $23.0(2.00)$ & $8.0(4.58)$ \\
\hline Canarium madagascariense & 2400 & 4 & $37.8(4.19)^{\mathrm{b}}$ & $77.0(2.71)$ & $35.5(2.16)^{\mathrm{a}}$ & $34.5(2.99)^{\mathrm{a}}$ & $33.8(0.96)^{\mathrm{b}}$ & $26.0(1.41)$ \\
\hline Chrysophyllum boivinianum & 3000 & 5 & $62.0(2.65)^{\mathrm{a}}$ & $65.0(3.39)^{\mathrm{a}}$ & $72.0(3.24)^{\mathrm{b}}$ & $72.0(4.30)^{\mathrm{b}}$ & $22.0(2.55)^{\mathrm{c}}$ & $16.0(3.24)^{\mathrm{c}}$ \\
\hline Chrysophyllum perrieri & 1800 & 3 & $73.0(0.58)^{\mathrm{a}}$ & $77.5(2.00)^{\mathrm{a}}$ & $82.0(2.52)^{\mathrm{a}}$ & $80.0(2.65)^{\mathrm{a}}$ & $34.3(1.53)^{\mathrm{b}}$ & $36.0(2.65)^{\mathrm{b}}$ \\
\hline Coffea perrieri & 2400 & 4 & $47.8(2.87)$ & $75.0(2.16)$ & $65.0(4.24)^{\mathrm{a}}$ & $67.0(3.16)^{\mathrm{a}}$ & $16.8(2.75)^{\mathrm{b}}$ & $13.0(4.24)^{b}$ \\
\hline Cryptocarya dealbata & 1800 & 3 & $47.7(1.53)^{\mathrm{ac}}$ & $41.0(1.73)^{\mathrm{c}}$ & $53.0(2.65)^{\mathrm{ab}}$ & $59.0(3.61)^{\mathrm{b}}$ & $41.0(2.65)^{\mathrm{c}}$ & $41.0(2.00)^{\mathrm{c}}$ \\
\hline Cryptocarya ovalifolia & 1800 & 3 & $40.0(2.65)^{\mathrm{ac}}$ & $46.0(1.00)^{\mathrm{a}}$ & $66.0(2.65)$ & $33.0(3.00)^{\mathrm{bd}}$ & $31.0(2.00)^{\mathrm{b}}$ & $39.0(2.65)^{\mathrm{cd}}$ \\
\hline Cryptocarya thouvenotii & 1800 & 3 & $44.0(2.00)^{\mathrm{a}}$ & $32.3(2.52)^{\mathrm{b}}$ & $33.3(4.04)^{\mathrm{b}}$ & $32.3(4.51)^{\mathrm{b}}$ & $39.0(3.61)^{\mathrm{ab}}$ & $59.3(4.16)$ \\
\hline Dichapetalum chlorinum & 1800 & 3 & $70.0(2.65)^{\mathrm{a}}$ & $73.0(2.65)^{\mathrm{a}}$ & & $67.0(3.61)^{\mathrm{a}}$ & $17.0(3.00)^{\mathrm{b}}$ & $11.0(2.65)^{\mathrm{b}}$ \\
\hline Dypsis fibrosa & 1800 & 3 & $32.0(4.36)^{\mathrm{a}}$ & $24.0(2.65)$ & $48.0(1.73)$ & $32.0(2.00)^{\mathrm{a}}$ & $7.0(3.61)^{\mathrm{b}}$ & $3.0(2.00)^{\mathrm{b}}$ \\
\hline Dypsis mananjarensis & 2400 & 4 & $22.0(1.83)^{\mathrm{a}}$ & $21.0(2.94)^{\mathrm{a}}$ & $12.0(2.45)^{\mathrm{b}}$ & $13.3(1.71)^{\mathrm{b}}$ & $1.0(0.82)^{\mathrm{c}}$ & $0.0(0.00)^{\mathrm{c}}$ \\
\hline Landolphia aff. gummifera & 1800 & 3 & $71.0(2.65)^{\mathrm{a}}$ & $89.0(2.65)$ & $71.0(2.00)^{\mathrm{a}}$ & $48.0(2.00)^{\mathrm{b}}$ & $59.3(3.21)$ & $48.0(2.00)^{\mathrm{b}}$ \\
\hline Macphersonia gracilis & 1800 & 3 & $80.0(3.00)$ & $92.0(1.73)$ & $72.0(3.00)^{\mathrm{a}}$ & $72.0(2.65)^{\mathrm{a}}$ & $8.0(1.73)^{\mathrm{b}}$ & $8.0(2.65)^{\mathrm{b}}$ \\
\hline Mendoncia cowanii & 1800 & 3 & $60.0(2.65)^{\mathrm{a}}$ & $57.0(3.00)^{\mathrm{a}}$ & $61.0(3.46)^{\mathrm{a}}$ & $53.0(6.08)^{\mathrm{a}}$ & $23.0(2.65)^{\mathrm{b}}$ & $17.0(3.61)^{b}$ \\
\hline Noronhia introversa & 2400 & 4 & $100.0(0.00)^{\mathrm{a}}$ & $90.0(2.16)^{b}$ & $100.0(0.00)^{\mathrm{a}}$ & $100.0(0.00)^{\mathrm{a}}$ & $100.0(0.00)^{\mathrm{a}}$ & $90.0(2.16)^{\mathrm{b}}$ \\
\hline Noronhia urceolata & 1800 & 3 & $96.0(2.65)^{a b c}$ & $100.0(0.00)^{\mathrm{a}}$ & $98.3(2.08)^{\mathrm{ab}}$ & $100.0(0.00)^{\mathrm{a}}$ & $94.0(3.00)^{b c}$ & $92.0(2.65)^{\mathrm{c}}$ \\
\hline Ocotea nervosa & 1800 & 3 & $43.0(3.00)$ & $72.0(2.65)^{\mathrm{a}}$ & $72.0(2.65)^{\mathrm{a}}$ & $29.0(3.46)$ & $0.0(0.00)^{\mathrm{b}}$ & $0.0(0.00)^{\mathrm{b}}$ \\
\hline Poupartia chapelieri & 1800 & 3 & $67.0(3.46)^{\mathrm{ab}}$ & $73.0(2.00)^{\mathrm{a}}$ & $64.3(3.51)^{\mathrm{b}}$ & $69.0(3.00)^{\mathrm{ab}}$ & $0.0(0.00)^{\mathrm{c}}$ & $0.0(0.00)^{\mathrm{c}}$ \\
\hline Protium madagascariensis & 1800 & 3 & $66.7(1.53)^{\mathrm{b}}$ & $73.3(1.15)^{\mathrm{a}}$ & $64.7(3.21)^{\mathrm{b}}$ & $69.3(2.08)^{\mathrm{ab}}$ & $0.0(0.00)^{c}$ & $0.0(0.00)^{\mathrm{c}}$ \\
\hline Salacia madagascariensis & 1800 & 3 & $50.0(4.36)^{\mathrm{a}}$ & $66.0(1.00)^{b}$ & $56.0(3.61)^{\mathrm{ac}}$ & $64.0(4.36)^{b c}$ & $10.0(3.00)^{\mathrm{d}}$ & $8.7(4.16)^{\mathrm{d}}$ \\
\hline Sideroxylon betsimisarakum & 1200 & 2 & $44.5(3.54)^{\mathrm{a}}$ & $66.0(1.41)^{\mathrm{b}}$ & $56.0(4.24)^{\mathrm{ab}}$ & $64.5(3.54)^{\mathrm{b}}$ & $10.0(4.24)^{\mathrm{c}}$ & $8.0(1.41)^{\mathrm{c}}$ \\
\hline Suregada celastroides & 1800 & 3 & $85.3(2.52)^{\mathrm{a}}$ & $90.7(3.06)^{\mathrm{a}}$ & $72.3(2.52)^{\mathrm{b}}$ & $76.0(2.65)^{b}$ & $31.0(1.00)^{\mathrm{c}}$ & $33.0(4.58)^{\mathrm{c}}$ \\
\hline Syzygium bernieri & 1800 & 3 & $94.0(2.00)^{\mathrm{a}}$ & $94.0(2.65)^{\mathrm{a}}$ & $90.7(2.52)^{\mathrm{a}}$ & $90.0(4.00)^{\mathrm{a}}$ & $46.7(3.06)$ & $36.7(4.04)$ \\
\hline Tina apiculata & 1800 & 3 & $78.0(3.00)^{\mathrm{a}}$ & $50.0(4.36)$ & $68.3(2.52)^{\mathrm{b}}$ & $70.0(4.36)^{\mathrm{ab}}$ & $20.0(3.61)^{c}$ & $14.0(1.73)^{c}$ \\
\hline Treculia madagascarica & 1800 & 3 & $44.0(1.15)$ & $62.0(3.51)$ & $36.0(3.06)$ & $58.0(3.00)$ & $20.0(2.65)^{\mathrm{a}}$ & $17.0(2.52)^{\mathrm{a}}$ \\
\hline Trophis montana & 1800 & 3 & $78.0(3.00)^{\mathrm{a}}$ & $81.7(2.08)^{\mathrm{a}}$ & $54.3(3.52)^{\mathrm{b}}$ & $56.0(4.58)^{\mathrm{b}}$ & $32.3(1.15)$ & $21.3(3.06)$ \\
\hline Uapaca thouarsii & 3000 & 5 & $67.0(0.96)^{\mathrm{a}}$ & $73.0(2.65)$ & $66.8(1.71)^{\mathrm{a}}$ & $67.2(3.42)^{\mathrm{a}}$ & $50.0(2.94)$ & $43.0(3.51)$ \\
\hline Uvaria combretifolia & 2400 & 4 & $76.0(1.41)$ & $88.0(2.16)$ & $68.0(1.41)^{\mathrm{a}}$ & $68.0(1.41)^{\mathrm{a}}$ & $7.0(2.16)^{b}$ & $8.0(2.58)^{b}$ \\
\hline
\end{tabular}

The timber species Khaya madagascariensis (87.2\%), Cryptocarya dealbata (85.4\%), and Suregada celastroides $(81.8 \%)$ had the highest seedling survival from nursery to corridor in this tier, which decreased to $39.0 \%$ for Croton mongue (Table 3). The seedling survival data for C. dealbata and $S$. celastroides for the Timber Tier is independent of the Permanent Tier. All Dalbergia madagascariensis seedlings survived through the evaluation period, although very few were planted in comparison to most other species. This sought-after rosewood species attained the least amount of height amongst the timber species, but it expanded its girth quicker than others.

Eight species were selected for the Non-Timber Tier. The survival rates of Tamarindus indica and Persea americana 
TABLE 3: Percent survival and growth rates of seedlings in the corridor.

\begin{tabular}{|c|c|c|c|c|c|}
\hline \multirow{2}{*}{ Tier } & \multirow{2}{*}{ Scientific name } & \multirow{2}{*}{ Seedlings planted } & \multirow{2}{*}{ Seedling survival (\%) } & \multicolumn{2}{|c|}{ Average growth rate ( $\mathrm{cm} /$ month) } \\
\hline & & & & Basal diameter & Height \\
\hline \multirow[t]{4}{*}{ Permanent Tier (Pioneer) } & Albizia chinensis & 686 & 87.4 & 0.20 & 18.72 \\
\hline & Albizia lebbeck & 802 & 26.6 & 0.07 & 5.06 \\
\hline & Albizia saman & 2976 & 97.5 & 0.12 & 4.90 \\
\hline & Harungana madagascariensis & 2940 & 94.7 & 0.06 & 4.31 \\
\hline \multirow[t]{37}{*}{ Permanent Tier (Secondary) } & Abrahamia aff. sericea & 340 & 78.3 & 0.06 & 4.00 \\
\hline & Anthocleista longifolia & 6 & 100.0 & 0.08 & 3.66 \\
\hline & Aspidostemon aff. perrieri & 101 & 50.9 & 0.05 & 3.61 \\
\hline & Bathiorhamnus louvelii & 400 & 47.7 & 0.05 & 2.80 \\
\hline & Bathiorhamnus macrocarpus & 17 & 33.3 & 0.05 & 2.50 \\
\hline & Beilschmiedia opposita & 50 & 80.0 & 0.03 & 2.00 \\
\hline & Burasaia madagascariensis & 26 & 49.0 & 0.05 & 2.60 \\
\hline & Canarium boivinii & 305 & 85.9 & 0.11 & 7.01 \\
\hline & Canarium madagascariense & 357 & 81.4 & 0.10 & 7.28 \\
\hline & Chrysophyllum boivinianum & 534 & 13.9 & 0.05 & 1.60 \\
\hline & Chrysophyllum perrieri & 185 & 11.5 & 0.04 & 1.80 \\
\hline & Coffea perrieri & 72 & 60.0 & 0.04 & 2.40 \\
\hline & Cryptocarya dealbata & 43 & 86.2 & 0.06 & 2.80 \\
\hline & Cryptocarya ovalifolia & 105 & 57.1 & 0.06 & 2.64 \\
\hline & Cryptocarya thouvenotii & 117 & 58.5 & 0.05 & 2.56 \\
\hline & Dichapetalum chlorinum & 113 & 5.7 & 0.03 & 4.30 \\
\hline & Dupuya haraka & 42 & 22.2 & 0.04 & 3.00 \\
\hline & Dypsis fibrosa & 25 & 42.4 & 0.03 & 1.02 \\
\hline & Dypsis mananjarensis & 25 & 67.5 & 0.02 & 0.20 \\
\hline & Landolphia aff. gummifera & 15 & 33.3 & 0.06 & 2.80 \\
\hline & Macphersonia gracilis & 25 & 32.0 & 0.05 & 3.00 \\
\hline & Mendoncia cowanii & 412 & 11.4 & 0.03 & 4.10 \\
\hline & Noronhia introversa & 20 & 47.1 & 0.05 & 3.10 \\
\hline & Noronhia urceolata & 712 & 46.6 & 0.05 & 3.58 \\
\hline & Ocotea nervosa & 702 & 22.5 & 0.05 & 3.24 \\
\hline & Poupartia chapelieri & 17 & 66.7 & 0.06 & 2.80 \\
\hline & Protium madagascariensis & 46 & 84.2 & 0.06 & 2.60 \\
\hline & Salacia madagascariensis & 15 & 40.0 & 0.03 & 4.30 \\
\hline & Sideroxylon betsimisarakum & 10 & 37.5 & 0.05 & 2.00 \\
\hline & Streblus mauritianus & 265 & 100.0 & 0.06 & 6.82 \\
\hline & Suregada celastroides & 124 & 81.3 & 0.05 & 2.30 \\
\hline & Syzygium bernieri & 130 & 100.0 & 0.06 & 5.20 \\
\hline & Tina apiculata & 228 & 10.2 & 0.05 & 1.80 \\
\hline & Treculia madagascarica & 81 & 93.8 & 0.06 & 5.25 \\
\hline & Trophis montana & 20 & 35.0 & 0.06 & 4.71 \\
\hline & Uapaca thouarsii & 720 & 92.6 & 0.08 & 5.33 \\
\hline & Uvaria combretifolia & 42 & 18.8 & 0.03 & 4.50 \\
\hline \multirow[t]{5}{*}{ Timber Tier } & Croton mongue & 1905 & 39.0 & 0.03 & 4.90 \\
\hline & Cryptocarya dealbata & 171 & 85.4 & 0.06 & 3.40 \\
\hline & Dalbergia madagascariensis & 40 & 100.0 & 0.09 & 3.08 \\
\hline & Khaya madagascariensis & 1613 & 87.2 & 0.06 & 4.80 \\
\hline & Suregada celastroides & 512 & 81.8 & 0.05 & 4.00 \\
\hline \multirow[t]{8}{*}{ Non-Timber Tier } & Anacardium occidentale & 117 & 80.0 & 0.16 & 5.40 \\
\hline & Annona muricata & 30 & 77.4 & 0.06 & 4.20 \\
\hline & Annona squamosa & 1014 & 75.7 & 0.16 & 5.14 \\
\hline & Cinnamomum camphora & 200 & 97.0 & 0.06 & 4.00 \\
\hline & Moringa oleifera & 1428 & 48.7 & 0.2 & 9.42 \\
\hline & Persea americana & 12 & 100.0 & 0.6 & 3.80 \\
\hline & Tamarindus indica & 8 & 100.0 & 0.07 & 5.10 \\
\hline & Theobroma cacao & 568 & 59.8 & 0.1 & 5.00 \\
\hline
\end{tabular}


trees were $100 \%$ during the evaluation period, although only a small number was planted. The survival rate of Cinnamomum camphora seedlings in the reforestation corridor was also high at $97 \%$. Moringa oleifera and Theobroma cacao had the lowest survival rates, $48.7 \%$ and $59.8 \%$, respectively. Both species of Annona had similar seedling survival rates (75.7$77.4 \%$ ), which were close to that of Anacardium occidentale at $80.0 \%$ (Table 3). Moringa oleifera is known for its medicinal properties and high protein foliage [39] as well as its waterclearing characteristics [40]. This tree had the highest growth rate of the Non-Timber Tier and expanded its girth faster than the quickest growing pioneer species, Albizia chinensis.

3.4. Community Participation. Fifty-eight people from the Kianjavato Commune attended the first of the reforestation village meetings. This meeting resulted in a pledge by Fokontany and villages of four sites for the nurseries and the enrollment of 22 private landholders in the reforestation pilot project. To prevent future disputes on land enrolled in the reforestation program, the MBP prepared contracts that were signed by community and government officials. These contracts stipulate that nurseries are donated in perpetuity to the fokonolona (the people of the Fokontany) and that participation in the program is contingent upon leaving the Permanent Tier intact. Participants are able to sustainably harvest from the lower $50 \%$ of the reforested land that represents the Timber and Non-Timber Tiers. The consequences of violating this agreement will be determined by a local environmental code and enforcement body that was reinvigorated to protect remnant forests as well as reforested areas. In total, approximately 3,400 seedlings were voluntarily planted by community members on three separate occasions in 2010 .

\section{Discussion}

Forest corridors increase the potential of maintaining viable populations of biota in fragmented landscapes by enhancing connectivity [41-45]. To improve the resilience of the corridor planted as part of the EPRP pilot project, a parallel corridor will be installed. This will create a zone between the corridors that is protected from anthropogenic disturbance thus promoting natural successional processes and expanding the width, a key factor expected to influence the vertebrate assemblage [46].

The high visibility tactic of linking the EPRP to the Critically Endangered black and white ruffed lemur maintains this species as a prominent subject of education events. Additionally, constant monitoring of groups reduces the opportunity for illegal hunting. Awareness efforts communicate the ecological services provided by $V$. variegata, a key seed disperser for Madagascar's lowland eastern forests [47], especially for large seeds that exceed the gape of smaller frugivorous lemurs. Overdorff and Strait [26] confirmed the efficiency of this lemur as a seed disperser based on its home range size, daily path lengths, and seed intactness after digestion. This study demonstrated that seeds subjected to gut passage generally have a higher germination percentage than those extracted from the fruit, as has been shown in other studies $[26,27]$. Therefore, these seeds are especially desirable for the quick and efficient production of seedlings for the reforestation effort. Five native tree species are possibly dependent on endozoochory for germination (Table 2); thereby restricting their use in more traditional reforestation programs. For the minority of species in this study whose germination was not affected by gut passage, the lemurs may still be important for dispersal away from the parent tree.

By extracting seeds from black and white ruffed lemur fecal samples from various collection sites, the EPRP built an inventory of genetically diverse large and small-seeded native tree species that were adapted to the environment. This provided high quality seedlings that are currently persisting through the establishment phase, which typically lasts between three and five years, while seedlings are in intense competition with weeds and especially vulnerable to environmental stresses [48].

A typical indicator of success during the establishment phase is the survival rate of trees [49]. For this study, seedling survival was generally higher in savoka near the forest edge than in adjacent areas of roranga. This may be attributed to differences in microclimate conditions such as soil nutriment, shade, and humidity. Dichapetalum chlorinum, Ocotea nervosa, Chrysophyllum boivinianum, C. perrieri, and Tinopsis apiculata were observed to be sensitive to sun exposure as these seedlings survived well under a moderate canopy but did poorly in open grasslands. A higher survival rate of seedlings planted in sites with remnant trees compared to those planted in sites without a tree canopy was also reported from a Mexican cloud forest [50] and in a mountain forest in Costa Rica [51].

Trends associated with poor seedling performance in exposed areas prompted the use of pioneers, especially Fabaceae species, to facilitate the growth and survival of young trees by ameliorating local microclimate conditions $[52,53]$, improving soil chemical and physical properties [52, 54], and suppressing aggressive grasses that could compete with forest seedlings [55, 56]. Three of the four pioneer species in this pilot program performed well with survival rates exceeding $80 \%$ in the corridor; however, two of the most successful species are not native, Albizia chinensis and A. saman (Table 3). The performance of Streblus maritianus, Syzygium bernieri, Treculia madagascariensis, and Uapaca thouarsii suggests that they could also be used as pioneers in reforestation efforts based on their survival rates in the nursery and the corridor as well as their high growth rates (Table 3 ). These species can shift the dependency on using introduced species as pioneers to native species in Madagascar's humid forest.

Forest trees growing in open areas often fruit years earlier than when in a closed forest as reproductive maturity for many canopy tree species may be triggered by exposure to full sun, inducing fruiting as early as three years after germination $[57,58]$. In this study, Albizia chinensis and Syzygium bernieri had fruit after 12 and three months, respectively. Establishment of a second generation of Malagasy native trees will be the first indication that the EPRP yielded a reproductive population of a target species. The growth and reproduction 
of these two fast-growing trees will result in stands stocked at 625 individuals/ha using the design of the pilot project and will facilitate natural regeneration by native woody plants in their understories [59].

Seedling predation was clearly a factor influencing seedling establishment as some trees were subject to high levels of herbivory. It is widely recognized that high tree mortality can result from the effects of insect herbivores [50]. However, the average survival rate of $56.1 \%$ for secondary species in this study is comparable to that of the restoration of Ambatotsirongorongo, a newly defined protected area in the coastal forest of southern Madagascar, which utilized native species with a survival rate of $51 \%$ [24]. This study also exceeds the mean survival rate of $42.1 \%$ after one year for seedlings planted in the perimeter of a forest on Madagascar's central high plateau [60]. This may be due to the use of herbaceous plant material removed in the process of planting the trees as mulch around the seedlings and manual weeding after one year.

Drayton and Primack $[61,62]$ stressed that the success of programs that aim to establish new populations of perennials should be measured by the presence of subsequent reproductive generations. The existence of these young individuals would be an indicator that the reforestation program has transitioned from the establishment to the building phase, the period during which trees grow, reproduce, and die [48]. Therefore, an effective evaluation strategy for the EPRP will be a long-term effort reflecting the time frame of the trees' life cycles.

Another measure of success will be the EPRP's longterm effect on the rate of conversion of forest to agricultural land. The slash and burn cropping system in Madagascar is deeply rooted in the country's culture, although it was only sustainable when the population was low. Farmers first cultivated the lower parts of valleys and moved slowly uphill, allowing fields to go fallow for years at a time to naturally rebuild their soil nutrient stocks [21]. However, the country's population is rapidly increasing, so fallow periods are becoming shorter and productivity is declining forcing farmers to deforest hills at alarming rates. Styger et al. [21] estimate that at the current fallow use frequency a rainforest can transition to roranga within 20-40 years and depending on the number of fallow cycles may require a minimum of 20 years before it is again capable of rice production.

This pilot project's reforestation area consisted of $80 \%$ roranga, a vegetation category that is unsuitable for the production of many staple crops. If roranga is burned, it transforms into "impoverished grasslands" that are relegated to cattle grazing and managed with an annual fire regime as only the youngest growth is palatable to livestock [21]. These grazing areas do not regenerate and are referred to as dead lands in some areas of the country [21]. Therefore, the presence of large areas of roranga should be warning flags for communities that survive as subsistence farmers. The EPRP may prevent that final transitional step of roranga to dead lands and is a model that could be introduced to other communities that are also on the cusp.

To maximize the probability of obtaining both physical (i.e., increasing forest cover and protecting biodiversity) and nonphysical (i.e., boost income, improve health, and raise environmental awareness) objectives, the EPRP addressed numerous drivers of reforestation success summarized by Le et al. [49]. These range from the reliable production of high quality seedlings adapted to the environment to the careful consideration of socioeconomic factors that influence the long-term maintenance of forested areas. Other reforestation projects in Madagascar [13, 24, 60] demonstrated that community participation increased the probability of success. Recognizing the need for sustained community support, the EPRP drew local residents into the planning and implementation phases and included landholders and nonlandholders.

The signing of contracts by individuals and government officials delineating the boundaries of reforested areas and stating the ownership of forest products assists with addressing future concerns that may arise related to tenure security. The development of business plans addressing harvesting, marketing, and distribution of profits intends to keep this reforestation model economically and financially viable for participating communities. A checks and balances system will be developed in collaboration with the local environmental enforcement body that outlines appropriate penalties for violation of land use laws. The Madagascar government is transferring management of a portion of its protected lands throughout the country to these small environmental enforcement organizations.

Madagascar's declining ability to effectively respond to natural disasters coupled with political instability highlights the need for grassroots efforts that combat apathy and empower individuals and communities. With the highest rate of poverty in Africa [63], Malagasy communities are unable to rely on governmental assistance and therefore must leverage their own resources to sustain themselves. The EPRP promotes a model that protects those resources, provides income via responsible long-term agricultural practices, and has the possibility of functioning without the continued presence of an NGO.

\section{Acknowledgments}

This research was supported by the generosity of the Ahmanson Foundation, Association of Zoological Horticulture, Association of Zoos and Aquariums Conservation Endowment Fund, Conservation International, Denver Zoo, Goggio Family Foundation, Irwin Andrew Porter Foundation, Margot Marsh Biodiversity Foundation, Mohamed bin Zayed Species Conservation Fund, Primate Action Fund, and an anonymous donor. This work would not have been possible without contributions from the Omaha Zoo Foundation, Omaha chapter of the American Association of Zoo Keepers, and the chapter of the Association of Zoo and Aquarium Docents, as well as V. J. and Angela Skutt Catholic High School in Omaha, NE, USA. The authors are especially grateful to Conservation Fusion Inc. and S. McGuire for their dedication to environmental education and for the support and advice of Kianjavato's mayor, S. Lan-Tu-Hin. The authors extend their thanks to the dedicated MBP nursery team of 
R. J. Razakatiana, V. T. Théoslas, L. André, and V. T. B. Nivo, as well as to J. Andrianasolo and MBP's committed drivers and office staff. The authors also wish to acknowledge the contributions of J. Taylor, A. Ginter, and S. Holmes.

\section{References}

[1] Institut National de la Statistique de Madagascar, Enquête périodique auprès des ménages 2010: rapport principal, Institut National de la Statistique/Direction des Statistiques des Ménages, Antananarivo, Madagascar, 2011.

[2] The World Bank, Sustaining Forests: A Development Strategy, The International Bank for Reconstruction and Development/The World Bank, Washington DC, USA, 2004.

[3] Maplecroft, "World's fastest growing populations increasingly vulnerable to the impacts of climate change - 4th global atlas reports," 2012, http://maplecroft.com/about/news/ccvi_2012 .html.

[4] N. Myers, R. A. Mittermeler, C. G. Mittermeler, G. A. B. da Fonseca, and J. Kent, "Biodiversity hotspots for conservation priorities," Nature, vol. 403, no. 6772, pp. 853-858, 2000.

[5] G. J. Harper, M. K. Steininger, C. J. Tucker, D. Juhn, and F. Hawkins, "Fifty years of deforestation and forest fragmentation in Madagascar," Environmental Conservation, vol. 34, no. 4, pp. 325-333, 2007.

[6] E. R. Patel, "Madagascar's illegal logging crisis: an update and discussion of possible solutions," Lemur News, vol. 15, pp. 2-7, 2010.

[7] C. Kremen, A. Cameron, A. Moilanen et al., "Aligning conservation priorities across taxa in Madagascar with high-resolution planning tools," Science, vol. 320, no. 5873, pp. 222-226, 2008.

[8] G. Smith and E. R. Ellis, "The impact of forest conservation policies on forest dependent communities in SE Madagascar: lessons for sustainability of Madagascar's new protected areas," WRM Bulletin 133, 2008, http://wrmbulletin.wordpress.com/ 2008/08/25/the-impact-of-forest-conservation-policies-on-forest-dependent-communities-in-se-madagascar-lessons-forsustainability-of-madagascars-new-protected-areas/.

[9] D. Lamb, P. D. Erskine, and J. A. Parrotta, "Restoration of degraded tropical forest landscapes," Science, vol. 310, no. 5754, pp. 1628-1632, 2005.

[10] J. A. Parrotta and O. H. Knowles, "Restoration of tropical moist forests on bauxite-mined lands in the Brazilian amazon," Restoration Ecology, vol. 7, no. 2, pp. 103-116, 1999.

[11] S. P. Goosem and N. I. J. Tucker, Repairing the RainforestTheory and Practice of Rainforest Re-Establishment in North Queensland's Wet Tropics, Wet Tropics Management Authority, Cairns, Australia, 1995.

[12] J. A. Parrotta, O. H. Knowles, and J. M. Wunderle Jr., "Development of floristic diversity in 10-year-old restoration forests on a bauxite mined site in Amazonia," Forest Ecology and Management, vol. 99, no. 1-2, pp. 21-42, 1997.

[13] L. Holloway, "Catalysing natural regeneration of rainforest: masoala corridors," Unpublished Report, Wildlife Conservation Society, Makira, Madagascar, 1997.

[14] O. H. Razafindratsima and E. Razafimahatratra, "Effect of red ruffed lemur gut passage on the germination of native rainforest plant species," Lemur News, vol. 15, pp. 39-42, 2010.

[15] J. M. Wunderle Jr., "The role of animal seed dispersal in accelerating native forest regeneration on degraded tropical lands," Forest Ecology and Management, vol. 99, no. 1-2, pp. 223$235,1997$.

[16] International Tropical Timber Organization (ITTO), ITTO Guidelines for the Restoration, Management and Rehabilitation of Degraded and Secondary Tropical Forests, ITTO Policy Development Series 13, International Tropical Timber Organization (ITTO), Yokohama, Japan, 2002.

[17] L. Holloway, "Ecosystem restoration and rehabilitation in Madagascar," Ecological Restoration, vol. 22, no. 2, pp. 113-119, 2004.

[18] P. H. Graham and C. P. Vance, "Legumes: importance and constraints to greater use," Plant Physiology, vol. 131, no. 3, pp. 872-877, 2003.

[19] K. C. Emberton, "Conservation priorities for forest-floor invertebrates of the Southeastern half of Madagascar: evidence from two land-snail clades," Biodiversity and Conservation, vol. 5, no. 6, pp. 729-741, 1996.

[20] A. Rasolohery, "Degraded humid forest," in Atlas of the Vegetation of Madagascar, J. Moat and P. Smith, Eds., p. 33, Kew Publishing, Surrey, UK, 2007.

[21] E. Styger, H. M. Rakotondramasy, M. J. Pfeffer, E. C. M. Fernandes, and D. M. Bates, "Influence of slash-and-burn farming practices on fallow succession and land degradation in the rainforest region of Madagascar," Agriculture, Ecosystems and Environment, vol. 119, no. 3-4, pp. 257-269, 2007.

[22] D. W. Gade, "Deforestation and its effects in Highland Madagascar," Mountain Research and Development, vol. 16, no. 2, pp. 101-116, 1996.

[23] O. E. Sala, F. S. Chapin III, J. J. Armesto et al., "Global biodiversity scenarios for the year 2100," Science, vol. 287, no. 5459, pp. 1770-1774, 2000.

[24] Conservation International, Restauration forestière à Madagascar: Capitalisation des experiences en vue de l'élaboration d'un Plan d'Action de Restauration, Conservation International, Antananarivo, Madagascar, 2011.

[25] K. Valenta and L. M. Fedigan, "Effects of gut passage, feces, and seed handling on latency and rate of germination in seeds consumed by capuchins (Cebus capucinus)," The American Journal of Physical Anthropology, vol. 138, no. 4, pp. 486-492, 2009.

[26] D. J. Overdorff and S. G. Strait, "Seed handling by three prosimian primates in Southeastern Madagascar: implications for seed dispersal," The American Journal of Primatology, vol. 45, no. 1, pp. 69-82, 1998.

[27] C. A. Chapman, "Primate seed dispersal: coevolution and conservation implications," Evolutionary Anthropology, vol. 4, no. 3, pp. 74-82, 1995.

[28] M. H. Faramalala and C. Rajeriarison, Etude de la végétation de Madagascar à l'aide des données spatiales [Ph.D. thesis], Université Paul Sabatier de Toulouse, 1988.

[29] Angiosperm Phylogeny Group III, "An update of the Angiosperm Phylogeny Group classification for the orders and families of flowering plants: APG III," Botanical Journal of the Linnean Society, vol. 161, no. 2, pp. 105-121, 2009.

[30] Madagascar Catalogue, Catalogue of the Vascular Plants of Madagascar, Missouri Botanical Garden, St. Louis, Mo, USA, Missouri Botanical Garden, Madagascar Research and Conservation Program, Antananarivo, Madagascar, 2012, http://www.efloras.org/madagascar.

[31] E. E. Louis Jr., J. H. Ratsimbazafy, V. R. Razakamaharauo, D. J. Pierson, R. C. Barber, and R. A. Brenneman, "Conservation 
genetics of black and white ruffed lemurs, Varecia variegata, from Southeastern Madagascar," Animal Conservation, vol. 8, no. 1, pp. 105-111, 2005.

[32] E. A. Williamson and A. T. C. Feistner, "Habituating primates: processes, techniques, variables and ethics," in Field and Laboratory Methods in Primatology: A Practical Guide, J. M. Setchell and D. J. Curtis, Eds., pp. 25-39, Cambridge University Press, Cambridge, UK, 2003.

[33] S. R. Day, R. E. A. F. Ramarokoto, B. D. Sitzmann et al., "Reintroduction of diademed sifaka (Propithecus diadema) and black and white ruffed lemurs (Varecia variegata editorum) at Analamazaotra Special Reserve, Eastern Madagascar," Lemur News, vol. 14, pp. 32-37, 2009.

[34] M. S. Comtet and R. Rabevohitra, "Contribution à l'étude de la flore forestière: Sur la germination de quelques essences forestières," FOFIFA Bulletin no. 6, 1991.

[35] C. Manjaribe, Essai de restauration écologique et rehabilitation de la forêt de Vohimana par plantation d'arbres [DEA thesis], Université d'Antananarivo, 2008.

[36] G. W. Sileshi, "A critique of current trends in the statistical analysis of seed germination and viability data," Seed Science Research, vol. 22, no. 3, pp. 145-159, 2012.

[37] K. Moder, "Alternatives to F-test in one way ANOVA in case of heterogeneity of variances (a simulation study)," Psychological Test and Assessment Modeling, vol. 52, pp. 343-353, 2010.

[38] H. W. Tukey, “The problem of multiple comparisons," Unpublished manuscript in the collected works of John W. Tukey VIII multiple comparisons: 1948-1983, Chapman \& Hall, New York, NY, USA, 1953.

[39] F. Anwar, S. Latif, M. Ashraf, and A. H. Gilani, "Moringa oleifera: a food plant with multiple medicinal uses," Phytotherapy Research, vol. 21, no. 1, pp. 17-25, 2007.

[40] M. Lea, "Bioremediation of turbid surface water using seed extract from Moringa oleifera Lam. (Drumstick) tree," Current Protocols in Microbiology, vol. 16, pp. 1G.2.1-1G.2.14, 2010.

[41] R. T. T. Forman, Land Mosaics: The Ecology of Landscapes and Regions, Cambridge University Press, Cambridge, UK, 1995.

[42] J. Kubeš, "Biocentres and corridors in a cultural landscape. A critical assessment of the 'territorial system of ecological stability," Landscape and Urban Planning, vol. 35, no. 4, pp. 231240, 1996.

[43] A. F. Bennett, Linkages in the Landscape: The Role of Corridors and Connectivity in Wildlife Conservation, IUCN, Cambridge, UK, 1998.

[44] D. R. Perault and M. V. Lomolino, "Corridors and mammal community structure across a fragmented, old-growth forest landscape," Ecological Monographs, vol. 70, no. 3, pp. 401-422, 2000.

[45] J. A. Hilty, W. Z. Lidicker, and A. M. Merenlender, Corridor Ecology: The Science and Practice of Linking Landscapes for Biodiversity Conservation, Island Press, Washington, DC, USA, 2006.

[46] A. C. Lees and C. A. Peres, "Conservation value of remnant riparian forest corridors of varying quality for Amazonian birds and mammals," Conservation Biology, vol. 22, no. 2, pp. 439449, 2008.

[47] J. L. Dew and P. C. Wright, "Frugivory and seed dispersal by four species of primates in Madagascar's eastern rain forest," Biotropica, vol. 30, no. 3, pp. 425-437, 1998.

[48] J. Kanowski and C. P. Catterall, Monitoring Revegetation Projects for Biodiversity in Rainforest Landscapes: Toolkit Version 1,
Revision 1, Marine and Tropical Sciences Research Facility Research Report Series, Reef and Rainforest Research Centre Limited, Cairns, Australia, 2007.

[49] H. D. Le, C. Smith, J. Herbohn, and S. Harrison, "More than just trees: assessing reforestation success in tropical developing countries," Journal of Rural Studies, vol. 28, no. 1, pp. 5-19, 2012.

[50] R. A. Pedraza and G. Williams-Linera, "Evaluation of native tree species for the rehabilitation of deforested areas in a Mexican cloud forest," New Forests, vol. 26, no. 1, pp. 83-99, 2003.

[51] K. D. Holl, M. E. Loik, E. H. V. Lin, and I. A. Samuels, “Tropical montane forest restoration in Costa Rica: overcoming barriers to dispersal and establishment," Restoration Ecology, vol. 8, no. 4, pp. 339-349, 2000.

[52] J. A. Parrotta, "Influence of overstory composition on understory colonization by native species in plantations on a degraded tropical site," Journal of Vegetation Science, vol. 6, no. 5, pp. 627636, 1995.

[53] D. C. Nepstad, C. Uhl, C. A. Pereira, and J. M. C. da Silva, "A comparative study of tree establishment in abandoned pasture and mature forest of Eastern Amazonia," Oikos, vol. 76, no. 1, pp. 25-39, 1996.

[54] P. M. S. Ashton, S. Gamage, I. A. U. N. Gunatilleke, and C. V. S. Gunatilleke, "Restoration of a Sri Lankan rainforest: using Carribean pine Pinus caribaea as a nurse for establishing latesuccessional tree species," Journal of Applied Ecology, vol. 34, no. 4, pp. 915-925, 1997.

[55] J. A. Parrotta, "The role of plantation forests in rehabilitating degraded tropical ecosystems," Agriculture, Ecosystems and Environment, vol. 41, no. 2, pp. 115-133, 1992.

[56] M. R. Guariguata, R. Rheingans, and F. Montagnini, "Early woody invasion under tree plantations in Costa Rica: implications for forest restoration," Restoration Ecology, vol. 3, no. 4, pp. 252-260, 1995.

[57] M. A. Huston, The effect of soil nutrients and light on tree growth and interactions during tropical forest succession: experiments in Costa Rica [Ph.D. thesis], University of Michigan, Ann Arbor, Mich, USA, 1982.

[58] D. A. Clark, "Plant demography," in La Selva: Ecology and Natural History of a Neotropical Rainforest, L. A. McDade, K. S. Bawa, H. A. Hespenheide, and G. S. Hartshorn, Eds., pp. 90105, University of Chicago Press, Chicago, Ill, USA, 1994.

[59] E. I. Damschen, N. M. Haddad, J. L. Orrock, J. J. Tewksbury, and D. J. Levey, "Corridors increase plant species richness at large scales," Science, vol. 313, no. 5791, pp. 1284-1286, 2006.

[60] I. Pareliussen, E. G. A. Olsson, and W. S. Armbruster, "Factors limiting the survival of native tree seedlings used in conservation efforts at the edges of forest fragments in upland Madagascar," Restoration Ecology, vol. 14, no. 2, pp. 196-203, 2006.

[61] R. B. Primack and B. Drayton, "The experimental ecology of reintroduction," Plant Talk, vol. 11, pp. 25-28, 1997.

[62] B. Drayton and R. B. Primack, "Success rates for reintroductions of eight perennial plant species after 15 years," Restoration Ecology, vol. 20, no. 3, pp. 299-303, 2012.

[63] World Bank Group, "Madagascar overview," 2012, http://www .worldbank.org/en/country/madagascar/overview. 

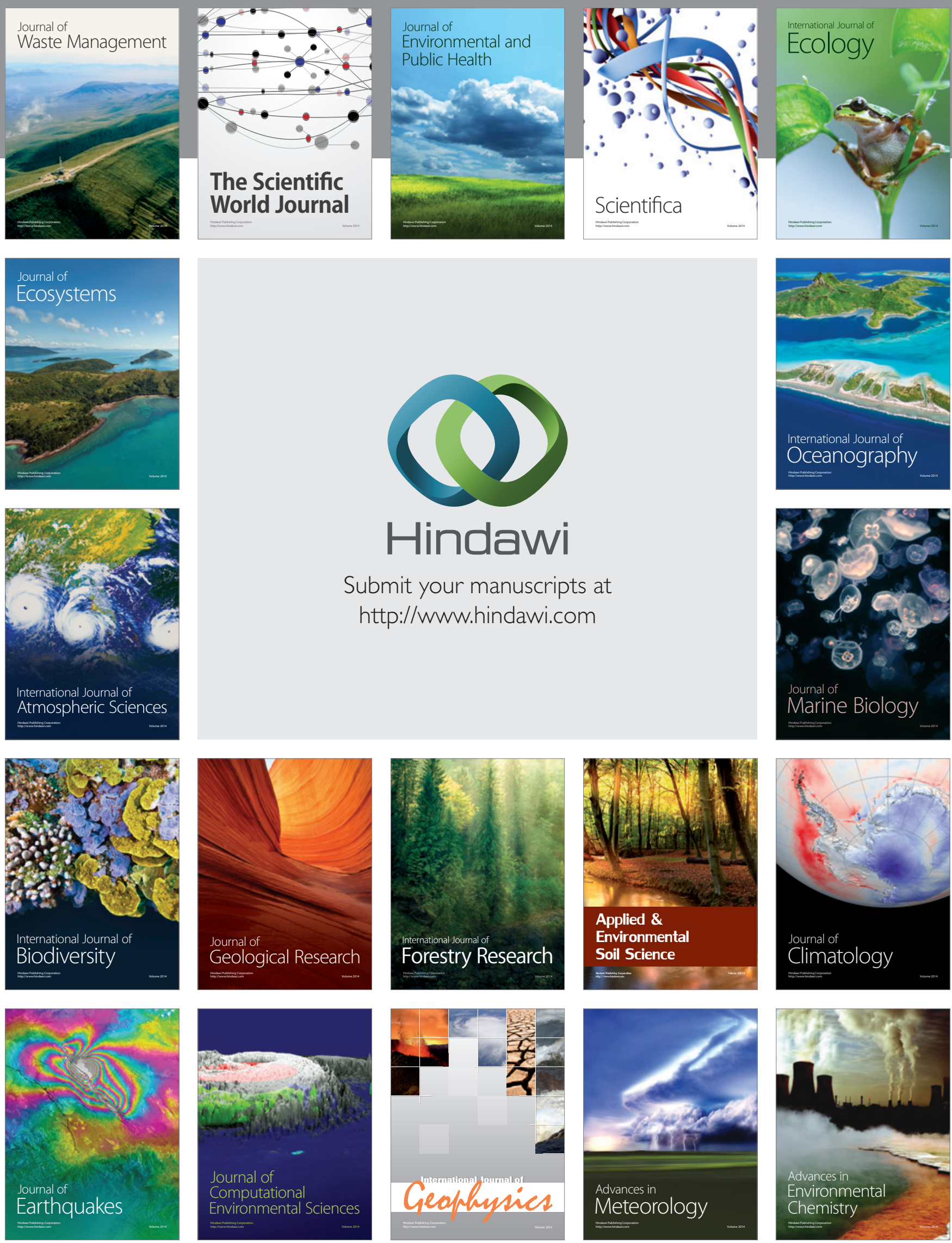